\title{
LIFE HISTORY OF ICHTHYURA STRIGOSA GROTE.
}

\author{
BY HARRISON G. DYAR, NEW YORK CITY.
}

Larua. Closely like that of I. apicalis; much paler in the early stages, darker in the last stage, the head black, not brown, the body of a dark purplish color, but marked in exactly the same pattern as $I$. apicalis.

$\boldsymbol{E}$ ggss. Laid in patches of 25 to 50 on the under side of leaves of Populus tremuloides at Jefferson Highlands, N. H., in June. Somewhat conoidal, not exactly hemispherical, when fresh not shining bright emerald green, later of a purplish color, the heads of the enclosed larvæ showing as black spots at the vertices; shell milky white; reticulations evident, neat, but narrow, almost linear and rather small, hexagonal with rounded angles, a small, better marked area at the vertex. Diameter, $8 \mathrm{~mm}$.; height, $5 \mathrm{~mm}$.

On hatching the larvæ do not run off as apicalis does, but begin to form their houses without wandering. They are less solitary in habit than apicalis.

Stage $I$. Head rather cordate, mouth pointed; shining black; width about $4 \mathrm{~mm}$. Body slightly flattened, grayish white, the slight elevation on joint $\mathrm{I} 2$ vinous brown and all of the sides thinly mottled with the same color; cervical shield black, anal plate vinous; thoracic feet black. The vinous on the sides is very obscure, being most pronounced in a narrow subdorsal line. Setæ single, long, dark at base, normal, vi absent, though represented by a slight tubercle without seta; leg plate distinct; on thorax no subprimary setæ, vi with two hairs; the two lower setæ of cervical shield detached. Skin covered with cuticular points.

Stage $I I$. Tubercles converted into small warts with a few secondary hairs from the skin besides. On abdomen normal, vi present; on thorax the setæ of $\mathrm{i}$ and ii unite to form three warts, the upper one small. Head slightly bilobed, shining black; width
$7 \mathrm{~mm}$. Body pale yellow dorsally on joints 3 to 12 with three faint purplish lines: cervical shield and anal plate smoky; a central purple spot on joints 5 and 12 , the latter joint a little enlarged. A sub-dorsal, purplebrown mottled line and faint mottlings on the sides; feet and leg plates dusky. Hairs pale, some of them long. Later the pale parts predominate so that the body appears multilineate with pale, the warts yellow.

Stage III. Width of head I.I $\mathrm{mm}$.

Stage IV. Head bilobed, shining black with many soft white hairs; medium suture deep, clypeus small, triangular, sunken below the bulging lobes; width, $2 \mathrm{~mm}$. The body appears as before - a whitish ground, traversed by faint triple dorsal, triple approximate lateral and double stigmatal broken, narrow, purplish brown bands, the dorsal ones fainter than the others. Central dorsal spots behind tubercle $\mathrm{i}$ on joints 5 and 12 , brown, no humps; warts all yellow. Primary and secondary hairs soft, pale, not long.

Stage $V$. Head black, the broad, high clypeus pale, scarcely sunken; width $3.2 \mathrm{~mm}$. Body as before, the dorsal patches on joints 5 and 12 much fainter; warts conspicuously yellow. The pale brown mottled lines are broader than the five intervening spaces on each side, mottled, pulverulent on a dirty whitish ground. A single example had the colors brighter, the lines red, "lake red," the three dorsal fainter than the lateral ones; tubercles yellow, the lateral ones giving the appearance of yellow lines alternating with the lateral red ones (as in Dr. Packard's description). Later as the larvæ mature the head becomes nearly entirely black, the lines dark dull purple, broad, mottled and freckled, reducing the ground color to narrow irregular pale lines. The 
general color is very uniform, the warts yellow but small and inconspicuous. Some of the whitish lines of the ground color are broken into ring-spots and streaks; about six remain on each side nearly continuous; the body is therefore dull dark purple, mottled with the narrow pale lines and rings and the small yellow tubercles. Hair very inconspicuous, fine, short, about one from each wart; secondary hair very fine, pilose. Spins an imperfect cocoon between leaves, the moth emerging the following season. The larvæ have the habits of $I$. apicalis (vau) living in houses formed of leaves spun together.

\section{BIBLIOGRAPHICAL NOTES. - VII.}

BY SAMUEL HENSHAW.

Minor Entomological Publications.GARDEN AND Forest. Vol. 5 (1892) contains the following notes and articles:-

Jack, J. G. The perforation of flowers [by bees]. p. 29-3o, fig. 7 .

S. The gypsy moth and its extermination. p. $8 \mathrm{I}-82$.

Smith, J. B. Insects in the soil of greenhouses. p. II 7 .

Nutter, F. H. Help against the gypsy moth. p. II 9 .

G., T. and Editor. Insects [Myzus cerasi] on cherry trees. p. 203-204.

Hoskins, T. H. Insecticides and fungicides in the orchard. p. $26 \mathrm{r}$.

L [odeman], E. G. The pear Psylla. p. 285 . Bailey, L. H. Is spraying overdone? p. 310. Jack, J. G. Notes on two [Cyllene robiniae, Aegeria rubi, Bembecia marginata] troublesome borers. p. 426 .

Editor. Legislation against injurious insects and plant diseases. p. 457-458.

Smith, J. B. Legislation against injurious insects. p. 490-49I.

Smith, J. B. The oak pruners [Elaphidion sp.]. p. 557-558, fig. 94-95.

Editor. Co-operation against insect invasions. p. 60I-6o2.
Slade, D.D. A campaign against the tent caterpillar. p. 604.

Vol. 6 (1893) contains the following: -

Wright, Walter C. Legislation against insects. p. 69-7o.

[Lintner, J. A.] A destructive elm tree bark borer [Saperda tridentata]. p. 75 .

Anon. [Notice of Smith's Cranberry insects]. p. 84 .

R[obbins, ] M. C. War upon caterpillars. p. 3I8-319.

A., E. B. and Editor. The white grub [Lachnosterna sp.] in lawns. p. 357 .

Smith, J. B. The white grub [Lachnosterna sp.] in lawns. p. 369 .

Editor. Legislation against plant diseases and injurious insects. p. 40I-402.

Smith, J. B. Notes on blister beetles [Meloidae]. p. 423-424.

[Rudd, W. N.] To kill grubs and seeds in greenhouse soil. p. 427 .

Smith, J. B. Is the woodpecker useful? [as a destroyer of insect larvae], p. 483-484.

Vol. 7 (1894) contains the following:-

Jack, J. G. The plum Curculio as an apple pest. p. 44-45.

Smith, J. B. The plum Curculio on apple. p. I04.

Anon. Review of Sempers's Injurious insects and the use of insecticides. p. 149 .

Orpet, E. O. The onion maggot. p. I87-188.

Anon. Review of. Adler's Alternating generations. p. 259-260.

Beach, S. A. A scale insect [Lecanium cerasifex] on plums. p. 284 , fig. 47 .

G., D. and Editor. Injuries by seventeen year locusts. p. 288.

Smith, J. B. The San José scale. p. 344, fig. 55 .

Hopkins, A. D. The relations of insects and birds to present forest conditions. p. 348.

Smith, J. B. The flat-head pear borer [Agrilus sinuatus]. p. 373-374, fig. 6o.

C., S. and Editor. Insects injurious to plants. p. 448. 

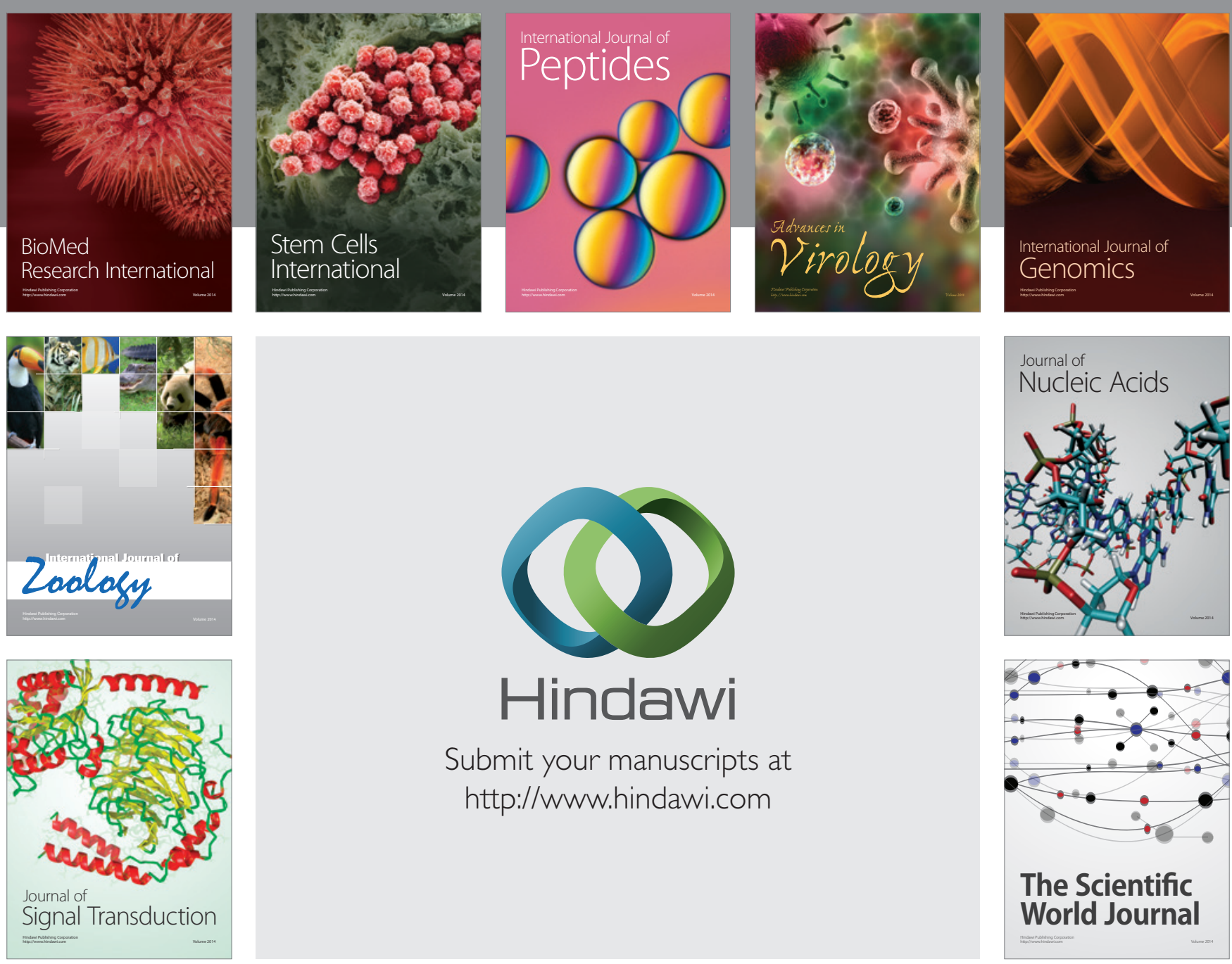

Submit your manuscripts at

http://www.hindawi.com
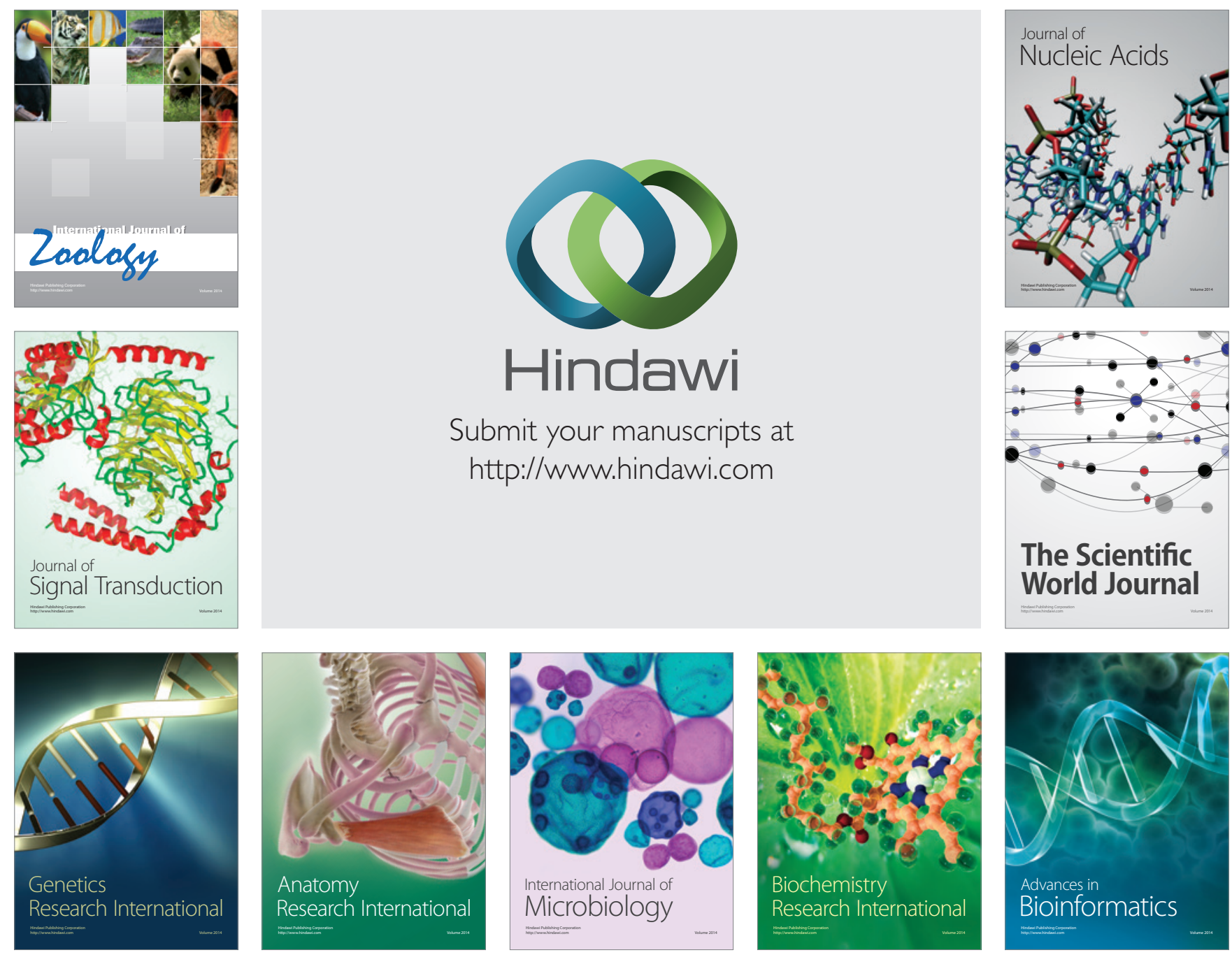

The Scientific World Journal
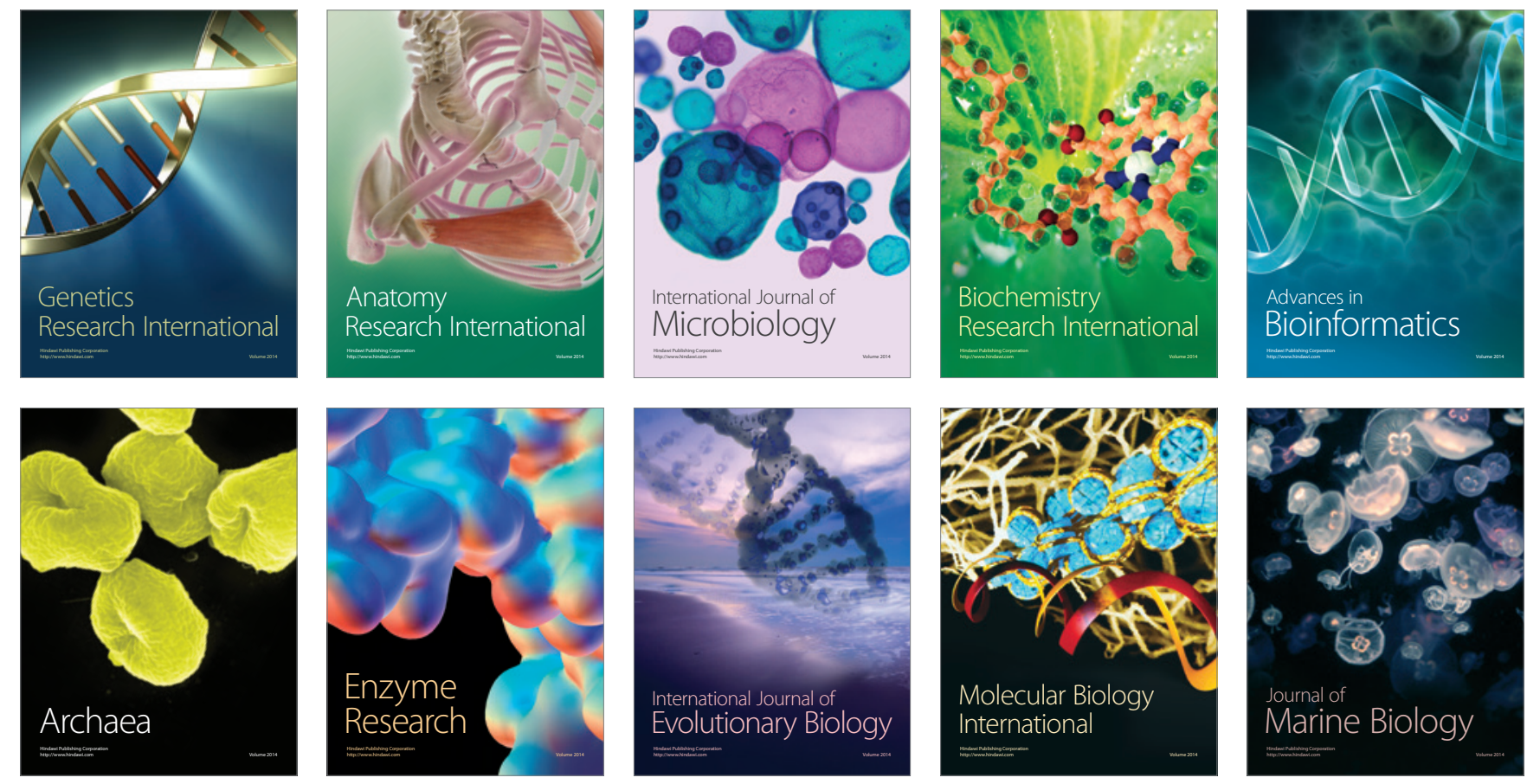